Review paper

\title{
ANTIFUNGAL ACTIVITIES OF PROPOLIS AND ITS MAIN COMPONENTS WITH AN EMPHASIS AGAINST PHYTOPATHOGENIC FUNGI
}

\author{
Auriane Dudoit ${ }^{1}$ \\ Nicolas Cardinault ${ }^{2}$ \\ Christian Mertz ${ }^{3}$ \\ Marc Chillet ${ }^{3}$ \\ Pierre Brat ${ }^{3 *}$ \\ 'UMR 1083 Sciences Pour L'@Enologie, Faculté des Sciences Pharmaceutiques et \\ Biologiques, Montpellier, France \\ 2Pollenergie, Saint-Hilaire-de-Lusignan, France \\ ${ }^{3}$ Cirad - UMR- Qualisud, Dpt Persyst Qualisud, Univ Montpellier, Avignon Université, \\ CIRAD, Institut Agro, IRD, Université de La Réunion, Montpellier, France \\ *corresponding author: pierre.brat@cirad.fr \\ Received: 17 June 2020; accepted: 17 March 2021
}

Abstract

Propolis is produced by honey bees from a series of resinous, gummy and balsamic substances collected from the leaf buds of different tree species and mixed with their secretions. It is used as a sealant and antiseptic in the hive. Because of its antimicrobial properties, propolis has become a popular alternative medicine or food for health protection and disease prevention. The presence of a large number of flavonoids, aromatic acids and phenolic compounds has been suggested to be responsible for most biological and pharmacological activities of propolis. This review aims to provide a critical analysis of the different studies which evaluate the activity of propolis against fungi and to identify the chemical components responsible for such activity. The discussion of the methodological approaches used and the issued results is a key point of this review to highlight knowledge gaps. This review will first describe the chemical composition of the propolis and the factors of variability including geographical and botanical origins and then examine its antifungal activities with a focus against phytopathogenic fungi. Finally, it will discuss the main components responsible for such activities and their mechanism of action.

Keywords: bee propolis, biomarkers, food preservation, mechanism of action, phytopathogenic fungi

\section{INTRODUCTION}

Propolis is a natural substance made by bees and may have various physico-chemical characteristics and biological properties, depending on its geographic and/or botanical origin. Its composition depends, of course, on the type of plants foraged by the worker bee at the collection site, but also on the climate conditions, the season and bee species. This variability induces a particular interest for the medicinal natural product. Propolis, rich in flavonoid compounds and phenolic acids, presents antimicrobial, antiviral, antitumoral and antifungal activities (Marcucci, 1995; Toreti et al., 2013). Currently, most research deals with human pathogens while only some on plant diseases and agriculture.

Basim et al. (2006) has demonstrated that propolis extract applied in agriculture affects the growing of with the control of thirteen bacteria phytopathogens, such as Agrobacterium tumefaciens, Erwinia amylovora or Agrobacterium vitis. However, a few studies have shown the activity of propolis on fungal phytopathogens. The majority of assays on fungal plant strains were carried out in laboratory conditions, but some of them demonstrated propolis efficacy in vivo (Barrera et al., 2015; Guginski-Piva et al., 2015; Mattiuz 
et al., 2015). Till now, propolis has demonstrated to be effective at in vitro conditions and on postharvest treatments. Further studies must be carried out to explore the applicability of this post-harvest treatment at the industrial level.

Currently, the vast majority of published reviews deal with the pharmaceutical-biological activities of propolis associated with chemical composition (Burdock, 1997; Banskota et al., 2001; Bankova, 2005; Ramos, 2007; Sforcin, 2007; Watanabe et al., 2011; Tolba et al., 2013; Bankova et al., 2014). Many reviews have focused on the chemical aspect and the botanical and geographical origins of propolis (Bankova et al., 2000; Salatino et al., 2005; Xu et al., 2009; Sawaya et al., 2011), but to our knowledge no review has been published on the efficacy of propolis extract against phytopathogenic fungi and its potential use in food preservation.

The purpose of this critical review is to present various aspects of the antifungal activity of propolis and its components against phytopathogenic fungi. First, we briefly report the historical use of propolis and its actual applications. Then, we provide some basic facts on the chemical composition of propolis. We also discuss the non-repeatability of some studies because of the lack of crucial methodological information. Without and information on propolis' origin and chemical composition, reproduction of the results could be highly problematic. We then provide a critical discussion of the experimental conditions used to evaluate propolis's antifungal activity. Finally, we critically discuss the repeatability of experimentation and different aspects of antifungal activity evaluation.

\section{Historical use of propolis}

The first accounts of propolis's benefits date back to the ancient Egyptians. They used it to embalm corpses due to its antiputrefactive properties. The Incas used propolis as an antipyretic agent to treat fevers (Silva-Carvalho et al., 2015).

Many ancient Greek and Roman manuscripts mention its preparation and use as a traditional medicine in various diseases and treatments (Ghedira et al., 2009). The first authors to describe its medicinal effects were Aristotle, Dioscorides and Hippocrates among the Greeks, and Pliny and Galen for the Romans (de Funari et al., 2007; Toreti et al., 2013). Propolis was used as for cicatrising and an antiseptic to treat wounds and, as a mouthwash. The texts spoke of propolis as a "cure for contusions and suppurating ailments". In Rome, doctors applied it for poultices (Garedew et al., 2004), and it was highly sought after and more expensive than honey. In battle, Roman legionaries carried with themselves a small quantity to treat any wounds. These curative uses were perpetuated in the Middle Ages and via Islamic medicine (Ferhoum, 2010; Fokt et al., 2010). In the $12^{\text {th }}$ century, propolis was used in Europe to treat mouth and throat infections (Ozcan et al., 2004), and as early as the $17^{\text {th }}$ century, it was listed as an official medicine of the London Pharmacopoeia and became very popular in Europe from that time, due to its antimicrobial activity.

In France, propolis first appeared in written documents only at the beginning of the $18^{\text {th }}$ century. It reached its zenith during the Boer War (1899-1902) in South Africa at the end of the $19^{\text {th }}$ century, when it was promoting as a disinfectant and antiseptic for wound healing and tissue regeneration (Ferhoum, 2010; Mora et al., 2011). In World War II, several Soviet clinics treated tuberculosis with propolis; the results were conclusive, with a reduction in lung problems and a notable recovery of appetite.

Its use has been well known for centuries, but the enthusiasm for it from a scientific point of view has considerably increased since the 1980s. For instance, a great deal of work has focused on gradually testing new therapeutic possibilities for this substance. The latest techniques have provided a better understanding of the mechanisms involved and the molecular signalling pathways at work. These discoveries suggest that propolis might be used in increasingly vast fields, including treating cancer, diabetes, cardiovascular or neurodegenerative diseases, but also in veterinary medicine, or agronomy. 
Table 1.

Chemical composition of propolis extracts depending on geographical origin

\begin{tabular}{|c|c|c|c|c|}
\hline Geographical origin & $\begin{array}{l}\text { Botanical genus and/ } \\
\text { or species }\end{array}$ & Bee type & Majority compounds & References \\
\hline $\begin{array}{l}\text { Turkey (10 different } \\
\text { regions) }\end{array}$ & ns & $\begin{array}{l}\text { Apis } \\
\text { mellifera }\end{array}$ & $\begin{array}{l}\text { Aromatic alcohol, alcohol, aromatic acid, } \\
\text { flavonoid }^{\dagger} \text { (flavone, flavanone, flavonol), } \\
\text { ketone, terpene }{ }^{\dagger} \text {, vitamin E, acid }\end{array}$ & [36] \\
\hline $\begin{array}{l}\text { Medellin, Antioquia, } \\
\text { Colombia }\end{array}$ & ns & $\begin{array}{l}\text { Apis } \\
\text { mellifera }\end{array}$ & $\begin{array}{c}\text { Isocupressic acid, (+)-agathadiol, epi- } \\
\text { 13-torulosol }\end{array}$ & [49] \\
\hline $\begin{array}{c}\text { ‘El Siambon' Tucuman, } \\
\text { Argentina }\end{array}$ & $\begin{array}{l}\text { Salix humboldiana, } \\
\text { Pinus, } \\
\text { Eucalyptus }\end{array}$ & $\begin{array}{l}\text { Apis } \\
\text { mellifera }\end{array}$ & Pinocembrin*, galangin* & [33] \\
\hline $\begin{array}{l}\text { Baoding County, } \\
\text { Hebei Province, China }\end{array}$ & ns & ns & $\begin{array}{c}\text { Pinobanksin, pinocembrin", chrysin, } \\
\text { galangin* }\end{array}$ & [46] \\
\hline $\begin{array}{c}\text { Tehran-Khojir, northern } \\
\text { Iran }\end{array}$ & $\begin{array}{l}\text { Populus (determined } \\
\text { by studying the } \\
\text { chemical composition } \\
\text { of propolis by GC-MS) }\end{array}$ & ns & $\begin{array}{c}\text { Pinobanksin*, pinobanksin-3-acetate, } \\
\text { pinocembrin*, pinostrobin, chrysin*, } \\
\text { galangin }{ }^{*}\end{array}$ & [44] \\
\hline Haramaya, Ethiopia & 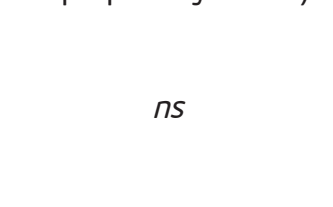 & $\begin{array}{l}\text { Apis } \\
\text { mellifera }\end{array}$ & $\begin{array}{c}\text { Benzenamine, N,N-dibutyl- } \\
\text { (21.94\%), Paromomycin (9.74\%), } \\
\text { 4-Aminobutyramide,N-methyl-N-[4-(1- } \\
\text { pyrrolidinyl)-2-butynyl]- }(9.26 \%) \text { and } \\
\text { DL-Tryptophan,5-methoxy(7.43\%) }\end{array}$ & {$[30]$} \\
\hline Northeastern Brazil & $\begin{array}{c}\text { Dalbergia ecastophyl- } \\
\text { lum }\end{array}$ & $\begin{array}{l}\text { Apis } \\
\text { mellifera }\end{array}$ & $\begin{array}{l}\text { Medicarpin, 3-hydroxy-8.9-dimeth- } \\
\text { oxypterocarpan, quercetin, chrysin*, } \\
\text { ferulic acid, artepillin } \mathrm{C}^{\dagger}\end{array}$ & [42] \\
\hline $\begin{array}{l}\text { Cabreuva, State of Sao } \\
\text { Paulo, Brazil }\end{array}$ & $\begin{array}{l}\text { Baccharis dracuncu- } \\
\text { lifolia }\end{array}$ & $\begin{array}{l}\text { Apis } \\
\text { mellifera }\end{array}$ & Artepillin C, p-Coumaric acid, kaempferid & {$[21,75]$} \\
\hline Temuco, Chile & ns & ns & $\begin{array}{l}\text { Pinocembrin*, caffeic acid*, myricetin, } \\
\text { quercetin, kaempferol, apigenin, galangin*, } \\
\text { caffeic acid phenyl ester (CAPE) }\end{array}$ & [39] \\
\hline State de Рarana, Brazil & $\begin{array}{l}\text { Baccharis dracunculi- } \\
\text { folia }+ \\
\text { Auraucaria spp. }\end{array}$ & ns & $\begin{array}{c}\text { 3,5-Diprenyl-4-hydroxycinnamic acid }{ }^{\dagger} \\
\text { (DHCA), 2,2-Dimethyl-6-carboxyethe- } \\
\text { nyl-2H-1-benzopyran (DCBEN), 3-Pre- } \\
\text { nyl-4-hydroxycinnamic acid (PHCA), } \\
\text { 2,2-Dimethyl-8-prenyl-2H-1-benzopyran- } \\
\text { 6-propenoic acid (DPB) }\end{array}$ & [76] \\
\hline $\begin{array}{c}\text { State of Minas Gerais, } \\
\text { Brazil }\end{array}$ & $\begin{array}{l}\text { Baccharis dracuncu- } \\
\text { lifolia }\end{array}$ & ns & $\begin{array}{c}\text { 3,5-Diprenyl-4-hydroxycinnamic acid } \\
\text { (DHCA), 3-Prenyl-4-hydroxycinnamic } \\
\text { acid }^{\dagger} \text { (PHCA), 2,2-Dimethyl-8-prenyl-2H- } \\
\text { 1-benzopyran-6-propenoic acid (DPB), } \\
\text { p-Coumaric acid (PCUM), Caffeic acid } \\
\text { (CA), caffeoylquinic acid derivates }\end{array}$ & [76], [77] \\
\hline State of Рагаna, Brazil & Auraucaria spp. & ns & $\begin{array}{l}\text { 3-Methoxy-4-hydroxy-benzaldehyde, } \\
\text { (VAN), 3-Methoxy-4-hydroxycinnamalde- } \\
\text { hyde (G2), 2-[1-hydroxymethyl]vinyl- } \\
\text { 6-acetyl-5-hidroxycumarane (I) }\end{array}$ & [76] \\
\hline Isfahan, central Iran & ns & ns & $\begin{array}{l}\text { Pinocembrin }{ }^{*} \text {, caffeic acid }{ }^{*} \text { kaempferol, } \\
\text { phenethyl caffeate, chrysin*, galangin }{ }^{*}\end{array}$ & [78] \\
\hline $\begin{array}{l}\text { England and New York } \\
\text { State, USA }\end{array}$ & ns & ns & p-coumaric acid, chrysin*, pinocembrin* & [77] \\
\hline Hatay region, Turkey & $\begin{array}{c}\text { pine forest, } \\
\text { eucalyptus, poplar } \\
\text { trees }\end{array}$ & $\begin{array}{c}\text { Apis } \\
\text { mellifera } \\
\text { syriaca, Apis } \\
\text { mellifera } \\
\text { anatoliaca, } \\
\text { Apis } \\
\text { mellifera } \\
\text { caucasica }\end{array}$ & Caffeic acid ${ }^{*}$, sesquiterpenes ${ }^{\dagger}$ & [79] \\
\hline
\end{tabular}


Table 1.

Chemical composition of propolis extracts depending on geographical origin

\begin{tabular}{|c|c|c|c|c|}
\hline Northeastern Portugal & nS & $\begin{array}{l}\text { Apis } \\
\text { mellifera }\end{array}$ & $\begin{array}{c}\text { New compound: } p \text {-coumaric ester } \\
\text { derivative dimer, methylated and/or } \\
\text { sterified or hydroxylated derivatives of } \\
\text { flavonoids, other compounds found in } \\
\text { temperate zones }\end{array}$ & [80] \\
\hline Greece & ns & ns & a-pinene & [81] \\
\hline Temuco, Chile & ns & ns & $\begin{array}{l}\text { Caffeic acid, myricetin, quercetin, } \\
\text { kaempferol, apigenin, pinocembrin*, } \\
\text { galangin, CAPE, rutin }\end{array}$ & {$[45]$} \\
\hline Sonora, Mexico & ns & ns & $\begin{array}{l}\text { Pinocembrin*, pinobanksin 3-acetate, } \\
\text { chrysin*, CAPE', acacetin, galangin* }\end{array}$ & {$[50]$} \\
\hline $\begin{array}{l}\text { Kangaroo Island, } \\
\text { Australia }\end{array}$ & Acacia paradoxa & $\begin{array}{l}\text { Apis } \\
\text { mellifera }\end{array}$ & $\begin{array}{c}\text { 2',3',4'-trimethoxychalcone } \\
\text { 2'-hydroxy-3',4'-dimethoxychalcone } \\
\text { 2',4'-dihydroxy-3'-methoxychalcone } \\
\text { pinobanksin 3-acetate } \\
\text { 5,7-dihydroxy-6-methoxy-2,3-dihydrofla- } \\
\text { vonol 3-acetate, }\end{array}$ & [82] \\
\hline Montevideo, Uruguay & ns & ns & $\begin{array}{c}\text { Pinobanksin 3-(2-methyl)butyrate pin- } \\
\text { obanksin 3-isobutyrate2-methyl-2-bute- } \\
\text { nyl ferulate }\end{array}$ & [83] \\
\hline Okinawa, Japan & Macaranga tanarius & $\begin{array}{l}\text { Apis } \\
\text { mellifera }\end{array}$ & $\begin{array}{l}\text { Nymphaeol-B, Isonymphaeol-B, Nymphae- } \\
\text { ol-A, 3'-geranyl-naringenin, Nymphaeol-C }\end{array}$ & [84] \\
\hline Waikato, New Zealand & ns & ns & $\begin{array}{l}\text { Pinobanksin*, pinocembrin*, chrysin*, } \\
\text { galangin*, cinnamic and ferulic acid }\end{array}$ & [47] \\
\hline
\end{tabular}

*antifungal compound, 'bioactive compound

ns - not shown

\section{Origin of propolis}

Propolis arised from an assembly between a plant resin and beeswax. The plant resin is harvested by worker bees (Apis mellifera L.) from the buds of certain trees, bushes, but also from young branches, leaf petioles and cracks in the bark of certain plants found in the ecosystem surrounding the hive. There are considered to be as many types of different propolis as there are ecosystems on the planet. Tab. 1 and 2 present a non-exhaustive list of the different propolis types existing in the world. Propolis in Europe is harvested almost exclusively from the buds of poplar trees (genus Populus) whereas in Brazil from Baccharis dracunculifolia and in Tunisia from Cistus sp.

This plant resin consists of wax secreted by bees and their saliva. The enzyme 13-glycosidase existing in bee saliva hydrolyses flavonoid glycosides into flavonoid aglycones (Ramos \& Miranda, 2007; Farooqui \& Farooqui, 2012) thereby giving rise to propolis. Its different physico-chemical characteristics mainly depend on its botanical origin. Its colour varies from yellow to green and from red to dark brown and depends on the type and age of the plant foraged by bees (Ghedira et al., 2009). The typical balsamic odour of propolis makes it easily recognisable. Poplar propolis can be hard and brittle in low temperatures and soft, rubbery and sticky in hot temperatures, while Baccharis propolis hard and friable at room temperature (Fokt et al., 2010). The materials available for "making" propolis are lipophilic substances produced by the surrounding plants in the bee ecosystem (Bankova, 2005).

In its ecology, the bee utilizes this malleable propolis as "cement", which is deposited inside the hive. In order to be perfectly viable, the hive must ensure a degree of imperviousness compatible with their various tasks (e.g. aeration of honey). Рropolis is therefore used to construct and repair the hive, plug holes and ensure it is sealed. However, paradoxically this imperviousness results in a confined space in which the thermal conditions $\left(34 \pm 2^{\circ} \mathrm{C}\right)$ and relative humidity (around $80 \%$ ) are conducive to the development of such pathogenic organisms 
Table 2.

Antifungal activity of propolis extracts against plant pathogens

\begin{tabular}{|c|c|c|c|c|c|c|}
\hline $\begin{array}{l}\text { Geographi- } \\
\text { cal origin }\end{array}$ & $\begin{array}{l}\text { Tested } \\
\text { extract }\end{array}$ & $\begin{array}{c}\text { Pathogen/ } \\
\text { Origin }\end{array}$ & $\begin{array}{l}\text { Analysed } \\
\text { parameter }\end{array}$ & Method & Results & References \\
\hline Turkey & EEP & $\begin{array}{l}\text { Aspergillus } \\
\text { versicolor } \\
\text { Penicillium au- } \\
\text { rantiogriseum } \\
\text { (isolated from } \\
\text { Turkish cheese) }\end{array}$ & $\begin{array}{l}\text { Percentage of } \\
\text { mycelium growth } \\
\text { inhibition }\end{array}$ & $\begin{array}{l}\text { Agar } \\
\text { medium } \\
\text { dilution } \\
\text { method }\end{array}$ & $\begin{array}{l}\text { Mycelium growth inhibition (\%) } \\
\text { EEP concentration 10\%: 100\% } \\
\text { inhibition on all the samples and the } \\
2 \text { strains } \\
\text { EEP concentration 5\%: >30\% } \\
\text { inhibition } \\
\text { EEP concentration 1\%: >15\% } \\
\text { inhibition }\end{array}$ & [36] \\
\hline $\begin{array}{l}\text { Hamaraya, } \\
\text { Ethiopia }\end{array}$ & EEP & $\begin{array}{l}\text { Fusarium sp. } \\
\text { Aspergillus } \\
\text { niger } \\
\text { (isolated from } \\
\text { avocado) }\end{array}$ & $\begin{array}{c}\text { Relative } \\
\text { inhibition of } \\
\text { mycelium growth }\end{array}$ & $\begin{array}{l}\text { Agar } \\
\text { medium } \\
\text { dilution } \\
\text { method }\end{array}$ & $\begin{array}{c}\text { Significant inhibition at a concentra- } \\
\text { tion of } 10 \mathrm{mg} \mathrm{mL}^{-1} \text { for Aspergillus } \\
\text { niger and Fusarium sp. }\end{array}$ & [30] \\
\hline $\begin{array}{l}5 \text { different } \\
\text { regions of } \\
\text { Turkey }\end{array}$ & MEP & $\begin{array}{l}\text { Alternaria } \\
\text { alternata } \\
\text { Fusarium } \\
\text { oxysporum }\end{array}$ & $\begin{array}{l}\text { Percentage of } \\
\text { mycelium growth } \\
\text { inhibition }\end{array}$ & $\begin{array}{l}\text { Agar } \\
\text { medium } \\
\text { dilution } \\
\text { method }\end{array}$ & $\begin{array}{l}\text { Mycelium growth inhibition (\%) } \\
\text { as of } D+3 \\
\text { F. oxysporum: } 100 \% \text { for } 2 \text { regions } \\
\text { (at } 2 \% \text { and } 5 \% \text { concentration) } \\
>52 \% \text { for the } 3 \text { others (from a } 2 \% \\
\text { concentration) } \\
\text { A. alternata. } 100 \% \text { for } 2 \text { regions at } \\
\text { a } 5 \% \text { concentration }\end{array}$ & [25] \\
\hline $\begin{array}{l}\text { Temuco, } \\
\text { Chile }\end{array}$ & EEP & $\begin{array}{c}\text { Alternaria } \\
\text { alternata } \\
\text { Fusarium sp. } \\
\text { Botrytis } \\
\text { cinerea } \\
\text { Penicillium } \\
\text { expansum }\end{array}$ & $\begin{array}{l}\text { Percentage of } \\
\text { mycelium growth } \\
\text { inhibition }\end{array}$ & $\begin{array}{l}\text { Agar } \\
\text { medium } \\
\text { dilution } \\
\text { method }\end{array}$ & $\begin{array}{l}100 \% \text { inhibition for all the fungi at } \\
\text { an EEP concentration = } 2.5 \% \text { except } \\
\text { for B.cinerea = at } 5 \% \\
\text { Inhibition still better than with the } \\
\text { chemical fungicide }\end{array}$ & [45] \\
\hline $\begin{array}{l}\text { Baoding } \\
\text { County, } \\
\text { Hebei } \\
\text { Province, } \\
\text { China }\end{array}$ & $\begin{array}{l}\text { EEP } \\
\mathrm{P}-\mathrm{Fr} \\
\mathrm{E}-\mathrm{Fr} \\
\mathrm{B}-\mathrm{Fr} \\
W-\mathrm{Fr}\end{array}$ & $\begin{array}{l}\text { Penicillium } \\
\text { italicum } \\
\text { (isolated from } \\
\text { citrus blue } \\
\text { mould) }\end{array}$ & $\begin{array}{l}\text { Percentage of } \\
\text { mycelium growth } \\
\text { inhibition }\end{array}$ & $\begin{array}{l}\text { Agar } \\
\text { medium } \\
\text { dilution } \\
\text { method }\end{array}$ & $\begin{array}{l}\text { Mycelium growth inhibition (\%) } \\
\text { EEP extract }\left(1200 \mathrm{mg} \mathrm{L}^{-1}\right): 93.20 \% \\
\text { P-Fr extract }\left(200 \mathrm{mg} \mathrm{L}^{-1}\right): 35.40 \% \\
\text { E-Fr extract }\left(200 \mathrm{mg} \mathrm{L}^{-1}\right): 100 \% \\
\text { B-Fr extract }\left(200 \mathrm{mg} \mathrm{L}^{-1}\right): 25 \% \\
\text { W-Fr extract }\left(200 \mathrm{mg} \mathrm{L}^{-1}\right): 6.82 \%\end{array}$ & [46] \\
\hline $\begin{array}{l}\text { Medellin, } \\
\text { Antioquia, } \\
\text { Colombia }\end{array}$ & $\begin{array}{l}\mathrm{EPEM} \\
\mathrm{CH}_{2} \mathrm{Cl}_{2} \\
\mathrm{EtOAC} \\
\mathrm{MeOH}\end{array}$ & $\begin{array}{c}\text { Colletotrichum } \\
\text { gloeospori- } \\
\text { oides } \\
\text { (isolated } \\
\text { from papaya } \\
\text { (Carica papaya) } \\
\text { and mango } \\
\text { (Mangifera } \\
\text { indica)) } \\
\text { Botryodiplodia } \\
\text { theobromae } \\
\text { (isolated from } \\
\text { avocado, } \\
\text { Persea } \\
\text { americana) }\end{array}$ & $\begin{array}{l}\text { Percentage of } \\
\text { mycelium growth } \\
\text { inhibition }\end{array}$ & $\begin{array}{l}\text { Agar } \\
\text { medium } \\
\text { dilution } \\
\text { method }\end{array}$ & $\begin{array}{l}\text { Mycelium growth inhibition (\%) } \\
\text { on C. gloeosporioides (mango), } \\
\text { C. gloeosporioides (papaya), } B . \\
\text { theobromae, respectively } \\
\text { EPEM extract: } 39.8 \%, 26.1 \%, 29 \% \\
\mathrm{CH}_{2} \mathrm{Cl}_{2} \text { extract: } 47.6 \%, 38.1,23.5 \% \\
\text { EtOAc extract: } 6.5 \%, 11.6 \%, 5.7 \% \\
\text { MeOH extract: } 9.9 \%, 5.2 \%, 4.9 \%\end{array}$ & [49] \\
\hline $\begin{array}{c}\text { Sao Paulo, } \\
\text { Brazil }\end{array}$ & EEP & $\begin{array}{l}\text { Colletotrichum } \\
\text { gloeospori- } \\
\text { oides }\end{array}$ & $\begin{array}{l}\text { Percentage of } \\
\text { mycelium growth } \\
\text { inhibition }\end{array}$ & $\begin{array}{l}\text { Agar } \\
\text { medium } \\
\text { dilution } \\
\text { method }\end{array}$ & $\begin{array}{l}\text { Mycelium growth inhibition (\%) } \\
\text { EEP concentration 2.5\%: total } \\
\text { inhibition } \\
\text { EEP concentration 0.5/1.0/1.5/2.0\%: } \\
\text { partial inhibition }\end{array}$ & [4] \\
\hline
\end{tabular}


Table 2.

Antifungal activity of propolis extracts against plant pathogens

\begin{tabular}{|c|c|c|c|c|c|c|}
\hline China & EEP & $\begin{array}{l}\text { Colletotrichum } \\
\text { capsici } \\
\text { (isolated from } \\
\text { capsicum) }\end{array}$ & $\begin{array}{l}\text { Percentage of } \\
\text { mycelium growth } \\
\text { inhibition }\end{array}$ & $\begin{array}{l}\text { Agar } \\
\text { medium } \\
\text { dilution } \\
\text { method }\end{array}$ & $\begin{array}{l}\text { Mycelium growth inhibition (\%) } \\
\text { EEP concentration 0.25\%: 66.1\% } \\
\text { inhibition } \\
\text { EEP concentration 0.50\%: 84.3\% } \\
\text { inhibition } \\
\text { EEP concentration 0.75\%: } 89 \% \\
\text { inhibition }\end{array}$ & [64] \\
\hline $\begin{array}{l}\text { Tehran- } \\
\text { Khojir, } \\
\text { northern } \\
\text { Iran }\end{array}$ & EEP & $\begin{array}{l}\text { Aspergillus } \\
\text { niger }\end{array}$ & $\begin{array}{l}\text { Determination of } \\
\text { MIC value }\end{array}$ & $\begin{array}{l}\text { Liquid } \\
\text { medium } \\
\text { dilution } \\
\text { method }\end{array}$ & $\begin{array}{c}\left.\text { MIC value ( } \mu \mathrm{g} \mathrm{mL}^{-1}\right) \\
\text { Aspergillus niger: } 500\end{array}$ & [44] \\
\hline $\begin{array}{l}\text { El-Aslogy, } \\
\text { Zagazig, } \\
\text { Egypt }\end{array}$ & EEP & $\begin{array}{l}\text { Aspergillus } \\
\quad \text { flavus } \\
\text { (isolated from } \\
\text { pealed peanut } \\
\text { seed) }\end{array}$ & $\begin{array}{l}\text { Percentage of } \\
\text { spore germina- } \\
\text { tion }\end{array}$ & $\begin{array}{l}\text { Liquid } \\
\text { medium } \\
\text { dilution } \\
\text { method }\end{array}$ & $\begin{array}{c}\text { For EEP concentrations varying } \\
\text { from } 3 \text { to } 4 \mathrm{~g}^{-1}: 56 \text { to } 76 \% \\
\text { reduction in spore germination } \\
\text { percentage }\end{array}$ & [57] \\
\hline $\begin{array}{l}\text { San Juan } \\
\text { province, } \\
\text { Argentina }\end{array}$ & EEP & $\begin{array}{l}\text { Aspergillus } \\
\text { flavus } \\
\text { Apsergillus } \\
\text { niger } \\
\text { Asneraillus }\end{array}$ & $\begin{array}{l}\text { Determination of } \\
\text { MIC value }\end{array}$ & $\begin{array}{l}\text { Liquid } \\
\text { medium } \\
\text { dilution } \\
\text { method }\end{array}$ & $\begin{array}{c}\text { Species of the genus Aspergillus are } \\
\text { not susceptible to extracts of urban } \\
\text { propolis (MIC > } 250 \mu \mathrm{mL}^{-1} \text { ) }\end{array}$ & [58] \\
\hline $\begin{array}{l}\text { 'El } \\
\text { Siambon' } \\
\text { Tucuman, } \\
\text { Argentina }\end{array}$ & PPPE & $\begin{array}{l}\text { niger (isolated } \\
\text { from citrus) } \\
\text { Fusarium sp. } \\
\text { Penicillium } \\
\text { notatum }\end{array}$ & $\begin{array}{l}\text { Determination of } \\
\text { MIC value }\end{array}$ & $\begin{array}{l}\text { Liquid } \\
\text { medium } \\
\text { dilution } \\
\text { method }\end{array}$ & $\begin{array}{l}\left.\text { MIC value ( } \mu \mathrm{g} \mathrm{mL}^{-1}\right) \\
\text { Aspergillus niger: } 232 \pm 0.12 \\
\text { Fusarium sp. (20), (21), (22): } \\
349 \pm 0.15,310 \pm 0.10,194 \pm 0.10 \\
\text { Penicillium notatum: } 349 \pm 0.14\end{array}$ & [33] \\
\hline $\begin{array}{l}\text { Sao Paulo, } \\
\text { Brazil }\end{array}$ & EEP & $\begin{array}{l}\text { Colletotrichum } \\
\text { gloeospori- } \\
\text { oides }\end{array}$ & $\begin{array}{l}\text { Percentage of } \\
\text { spore germina- } \\
\text { tion inhibition }\end{array}$ & $\begin{array}{l}\text { Liquid } \\
\text { medium } \\
\text { dilution } \\
\text { method }\end{array}$ & $\begin{array}{c}\text { Spore germination inhibition (\%) } \\
\text { EEP concentration 0.5\%: } 1.78 \% \\
\text { inhibition } \\
\text { EEP concentration 1.0\%: } 47.3 \% \\
\text { inhibition } \\
\text { EEP concentration 1.5\%: } 96.4 \% \\
\text { inhibition } \\
\text { EEP concentration 2.0\%: } 100 \% \\
\text { inhibition } \\
\text { EEP concentration 2.5\%: } 100 \% \\
\text { inhibition }\end{array}$ & [4] \\
\hline $\begin{array}{l}\text { 'El } \\
\text { Siambon' } \\
\text { Tucuman, } \\
\text { Argentina }\end{array}$ & PPPE & $\begin{array}{l}\text { Aspergillus } \\
\text { niger (isolated } \\
\text { from citrus) } \\
\text { Fusarium sp. } \\
\text { Penicillium } \\
\text { notatum }\end{array}$ & $\begin{array}{l}\text { Percentage of } \\
\text { mycelium growth } \\
\text { inhibition }\end{array}$ & $\begin{array}{l}\text { Paper } \\
\text { disc } \\
\text { diffusion } \\
\text { method }\end{array}$ & $\begin{array}{l}\text { Mycelium growth inhibition (\%) } \\
\text { Aspergillus niger: } 60.4 \pm 0.04 \\
\text { Fusarium sp. (20), (21), (22): } 63.1 \\
\pm 0.03,59.9 \pm 0.03,59.1 \pm 0.04 \\
\text { Penicillium notatum: } 44.6 \pm 0.05\end{array}$ & [33] \\
\hline $\begin{array}{c}\text { 'El } \\
\text { Siambon' } \\
\text { Tucuman, } \\
\text { Argentina }\end{array}$ & PPPE & $\begin{array}{l}\text { Aspergillus } \\
\text { niger (isolated } \\
\text { from citrus) } \\
\text { Fusarium sp. } \\
\text { Penicillium } \\
\text { notatum }\end{array}$ & $\begin{array}{l}\text { Compounds } \\
\text { displaying } \\
\text { activity potential }\end{array}$ & $\begin{array}{l}\text { TLC bio- } \\
\text { autogra- } \\
\text { phy }\end{array}$ & Discovery of phenolic compounds & [33] \\
\hline $\begin{array}{l}\text { Baoding } \\
\text { County, } \\
\text { Hebei } \\
\text { Province, } \\
\text { China }\end{array}$ & $\begin{array}{l}\text { EEP } \\
\mathrm{P}-\mathrm{Fr} \\
\mathrm{E}-\mathrm{Fr} \\
\mathrm{B}-\mathrm{Fr} \\
\mathrm{W}-\mathrm{Fr}\end{array}$ & $\begin{array}{l}\text { Penicillium } \\
\text { italicum } \\
\text { (isolated from } \\
\text { citrus blue } \\
\text { mould) }\end{array}$ & $\begin{array}{l}\text { Compounds } \\
\text { displaying } \\
\text { activity potential }\end{array}$ & $\begin{array}{l}\text { TLC bio- } \\
\text { autogra- } \\
\text { phy }\end{array}$ & $\begin{array}{l}\text { Identification: pinobanksin, pi- } \\
\text { nocembrin, chrysin, galangin }\end{array}$ & [46] \\
\hline
\end{tabular}

EEP, ethanol extract of propolis; EPEM, n-hexane/methanol extract of propolis; $\mathrm{CH}_{2} \mathrm{Cl}_{2}$, dichloromethane; EtOAc, ethyl acetate; $\mathrm{MeOH}$, methanol; PPPE, partially purified propolis extract ; P-Fr, petroleum ether fraction ; E-Fr, ethyl acetate fraction ; B-Fr, n-butanol fraction ; W-Fr, water fraction ; HPMC, hydroxypropylmethylcellulose. 
as bacteria or fungi (Ota et al., 2001). However, bees know how to harvest a substance that has the physical characteristics of "cement" and the chemical characteristics of an antimicrobial weapon. Indeed, propolis deposited in the hive has shown to prevent the decomposition of organic matter inside the hive by inhibiting microbial growth, as in mummifying the carcasses of invaders (Quiroga et al., 2006; Pietta et al., 2012).

The biological activities and antimicrobial properties of propolis are attributed to molecules that come exclusively from the foraged plant that provides the resin (Vardar-Ünlü et al., 2007). The survival of the species is ensured because bees adapt to their ecosystem by harvesting a resin which ensures the wholesomeness of the hive while protecting it from harmful microbes specific to the same ecosystem. The great natural variability in propolis depends on the type of plants foraged by the workers present at the collection site but also on climatic conditions, the season, and bee type.

\section{Current and future applications of propolis}

Now popular thanks to much available information, Propolis is considered as an alternative natural therapeutic, and propolis-based preparations as much surer and much less harmful tofor the health than numerous medicines (Castaldo \& Capasso, 2002). This renewed enthusiasm has motivated both researchers and the industry to continue investigating and broadening the fields of application for propolis (Temiz et al., 2013).

Over the last thirty years, intense research on propolis has confirmed or discovered numerous pharmaceutical and biological activities including antibacterial, antiviral, antifungal, antioxidant, anti-inflammatory, antitumoral and immunomodulating properties. The range of its medical applications has therefore been widely expanded. Current research covers medicine with some new therapeutic targets, as well as work in the cosmetics, food and the animal-care industries (Tosi et al., 2006).

Today, propolis can be administered either orally or systemically in the form of ampoules, infusions, syrups, tablets and capsules, or in topical applications such as toothpastes, pastilles-lozenges, mouth and nasal sprays (Almas et al., 2001; Ghedira et al., 2009). Mouthwashes and other dentifrices prevent tooth decay, gingivitis and stomatitis, and many formulations exist for treating allergies, inflammatory diseases, asthma, diabetes and hypertension and for use as a dietary supplement (Marcucci, 1995; Farooqui \& Farooqui, 2012). In Chile, propolis is consumed in very popular alcoholic and non-alcoholic beverages (Herrera et al., 2010). Almost all products available on the market are based on ethanol extracts of propolis, but industries also use glycerine and propylene glycol in product preparation (Ramos \& Miranda, 2007).

Despite the exteninsive and varied scientific literature on both the chemical composition and biological activities of propolis, most therapeutic applications remain limited primarily to human pathologies. Its application for food preservation in such fields as the agrifood sector or agriculture has seen little development. Despite the need for scientific knowledge on propolis, researchers or publishers encounter difficulties in ensuring that results published are repeatable and allow comparison, so as to extract usable and reproducible interpretations essential for application in the field.

\section{Chemical composition of propolis}

Many authors have claimed that the general composition of raw propolis (Tosi et al., 2006; Sawaya et al., 2011; Haile \& Dekebo, 2013; Nedji \& Loucif-Ayad, 2014) consists of around 50\% resin (containing the polyphenol fraction), 30\% beeswax (wax and fatty acid), 10\% essential oils (volatile compounds), $5 \%$ pollen (pollen protein and free amino acids) and 5\% other substances (vitamins, enzymes, steroids, etc.), referring to old articles, some dating back over seventy years. More recently, Bankova et al. (2014) has criticized those data and downwardly revised the volatile compound percentage, citing $1 \%$ and occasionally 2 to 3\%. Differences in appearance and textures between raw propolis samples from poplar Baccharis and Dalbergia suggest that these substances do not share the same general composition in percentage terms. An 
internal study (data not shown) showed that the distribution of resin/wax/others in propolis from poplar Baccharis and Dalbergia was 60-6040/20-10-20/20-30-40, respectively. As with any natural substance, raw propolis is variable. Factors of variability in the chemical composition of propolis include source plants, their availability at the time of collection, a hive's geographical origin, bee type, climate and season (Ghedira et al., 2009; Haile \& Dekebo, 2013). How raw propolis is harvested by humans could also be added to these natural elements.

Walker \& Crane (1987) first published a work inventorying plants in the world that supply propolis; however, authors working on its composition and consequently on its biological activities have rarely specified the botanical origin, and geographical origin is not enough to effectively describe a propolis sample. In Brazil for example, Park et al. (2004) demonstrated the existence of thirteen different chromatographic profiles from propolis samples taken throughout the Brazilian territory. Of all the molecules listed on those chromatograms, only two flavonoids and one phenolic acid were common to the thirteen types of Brazilian propolis, a new one displayed a bright red colour and its chemical composition differed from the other twelve types of propolis already inventoried. Silva et al. (2008) identified the botanical origin of this new propolis by comparing the chemical profile of ethanol extracts of the red propolis to those of resins collected from twenty different Brazilian plants. Only one plant, Dalbergia ecastaphyllum, had a virtually similar profile rich in isoflavonoids.

Tab. 1-2 give a list that is not exhaustive but matches information given in articles about propolis. Each article mentions the geographical origin of the propolis, while only $40 \%$ of them specify the botanical origin. For example, the table shows us that the majority of compounds found and identified by Mohammadzadeh et al. (2007) as coming from poplars in Iran were the same as those found in propolis from Chile (Herrera et al., 2010; Curifuta et al., 2012) and China (Yang et al., 2011). Although the botanical origin of those propolis samples was not mentioned, it is likely to have been poplars.
Markham et al. (1996) presented a propolis specific to New Zealand which was slightly similar to Manuka honey also from New Zealand. However, the authors stated that New Zealand had largely reintroduced the European poplar to its soil. Catchpole et al. (2004) qualified New Zealand propolis as a poplar propolis identical to European propolis. The composition of the red propolis from north-eastern Brazil, derived from Dalbergia, is similar to that of a red propolis rich in isoflavonoids, such as medicarpin and 3-hydroxy-8.9-dimethoxypterocarpan, found in Cuba's Pinar Del Rio province, proving the existence of the species Dalbergia in that region of Cuba (Meneses et al., 2009). In terms of the chemical composition of raw propolis, these different examples show how little importance the geographical origin carries when compared to the botanical origin.

Several authors have worked on seasonal impacts affecting propolis composition. One study compared the chemical composition of propolis samples from the same region of Sonora in Mexico over 4 consecutive seasons. The results of the chromatographic profiles obtained, and the relative abundance of the main peaks, did not reveal any significant difference (Valencia et al., 2012). Similar work had already been undertaken five years earlier at the same site, and again the comparison of the chromatograms did not reveal any significant difference. Nonetheless, a few differences were found for the relative abundance of certain non-majority compounds, which confirms that seasonality does not significantly influence quality but maybe quantitatively a few compounds, hence maybe biological activity.

To determine how bee type plays a role in the variability of propolis composition, some work was undertaken to analyse the volatile compounds of propolis samples harvested from various regions of Brazil with two different subspecies of Meliponinae bees. The percentages of different volatile compound families were compared using samples from the same place but with six different bee subspecies, including genus Plebia spp. and Tetragonisca angustula. In quantitative terms, two samples had diterpenic 
acids as did the majority family, three had triterpenic acids and the last sample had derivatives of benzoic acids. However, no qualitative analysis was undertaken, and instead bees of the subspecies Melipona quadrifasciata anthidioides were analysed in different geographical zones, for which some differences appeared. The author was unable to reach any conclusion regarding the species of bee or geographical origin, for determining the chemical composition of a propolis sample (Velikova et al., 2000). The enzyme and glandular system of bees were shown to not vary in terms of chemical composition, ans consequently the variations encountered in propolis composition are solely due to botanical origin (Bankova, 2005).

The chemical composition of raw propolis varies from a region with a tropical climate to a region with a temperate climate. In fact, in a temperate zone such as Europe propolis mainly comes from poplars, whereas in a country with a tropical climate such as Brazil, most propolis comes from Baccharis dracunculifolia or Auraucaria spp. Whilst not being a natural element, the propolis-harvesting method since the human domestication of bees has added a source of variation. For instance, Stan et al. (2011) showed that when poplar propolis is harvested with the screen method, the proportion of wax tends to not exceed $21 \%$, unlike the standard results obtained with the frame scraping method where the proportion largely exceeds 30\%. This difference in wax percentage is important because, physically, the drop in wax means a larger quantity of resin. As the latter is the sole source of the active ingredients for propolis, this suggests that the larger the proportion of resin, the greater will be the active ingredient contents.

Lastly, although as many sorts of propolis exists as there are different ecosystems on earth, only propolis from Baccharis, from poplars and more recently from Dalbergia have been widely studied. The botanical origin of these types of propolis was identified by the presence of molecular markers from the source plant. For instance, the main families of compounds encountered in poplar propolis are flavones (chrysin), flavanones (pinocembrin) and phenolic acids (caffeic acid), while a propolis derived from Baccharis is mostly composed of terpenoids and prenylated derivatives of $p$-cinnamic acid (artepillin C) and one derived from Dalbergia is composed of isoflavonoids (Bankova et al., 2002; Fokt et al., 2010).

We have seen that a number of natural and human factors exist which both govern and influence the composition of propolis in terms of its active ingredient. Given that the pharmaceutical-biological activities of propolis can be attributed to those same active ingredients, the botanical origin must be specified and no longer the geographical origin, which is of little interest. As shown in Tab. 1 and 2, many authors do not mention the botanical origin of propolis; the majority compounds are often listed but rarely quantified. Without that information, the repeatability of the work undertaken cannot be guaranteed. From now on, all studies will be more complete and precise as regards botanical origin, bee type and harvesting method, as these factors are decisive in the composition of propolis and thereby in the possibility of comparing certain biological activities of the same raw propolis.

\section{Antifungal activity of propolis}

Propolis has been known for its antimicrobial activity, and recently, a great deal of work on this natural substance has confirmed that property, while fine-tuning it for its antibacterial, antiviral and antifungal virtues. Even though many articles on human pathogens have reported on propolis as potential antifungal candidate (Dobrowolski et al., 1991; Ota et al., 2001; Dota et al., 2011), propolis is not officially recognized for its antifungal activity in the context of increasing antibiotic resistance. Some natural substances rich in flavonoids and phenolic acids have been shown to display an antifungal activity against such plant pathogenic fungi as Botrytis cinerea, Aspergillus niger and Alternaria alternata (Mohammadzadeh et al., 2007; Castro et al., 2009), yet there is little work with propolis on plant pathogens.

Despite this, those studies are representa- 
tive of the type of study undertaken as their design and the conclusions presented for human pathogens. We shall therefore study the different techniques used to assess the antifungal activity of propolis applied to plant pathogens. A critical analysis will be conducted on the inconsistencies, bias and lack of readability by certain authors regarding their expression of results, the protocols published and the interpretations made. The antifungal activity of propolis extracts is generally assessed through the study of mycelium growth or spore germination. The assessment of plant pathogen mycelium growth is most widely described in literature (Ghaly et al., 1998; Ozcan et al., 2004; Meneses et al., 2009; Yang et al., 2011; Temiz et al., 2013; Dudoit et al., 2020; Hosseini et al., 2020).

\section{Mycelium growth}

The dilution method and the diffusion method are mainly used to assess the effect of propolis extract on mycelium growth. The dilution method is widely used for assessing the antifungal activity of propolis and carried out in an agar medium or a liquid medium.

In an agar medium, the different concentrations of propolis liquid extract are incorporated into the agar prior to inoculation on the mycelium plug surface (Quiroga et al., 2006; Curifuta et al., 2012; Agüero et al., 2014). Mycelium growth inhibition is determined through the comparison of the mycelium radial growth diameter of the negative control (without propolis) with that of the tested extract (Bosio et al., 2000). In a liquid medium, the different concentrations of propolis liquid extract to be tested are incorporated into a spore suspension in a nutrient broth. After incubation, both mycelium growth and inhibition are determined with spectrophotometry (Hegazi et al., 2000). this method, also called the broth microdilution method, is most often used to determine the minimal inhibitory concentration (MIC) which corresponds to the lowest propolis extract concentration for which no microorganism growth is visible (fungistatic effect) (Quiroga et al., 2006; Mohammadzadeh et al., 2007; Agüero et al., 2014).
Although less common, the diffusion method can be carried out with the disc or well technique. The disc diffusion method consists of placing a paper disc imbibed with the propolis extract to be tested in different concentrations on the surface of the agar inoculated uniformly beforehand with a suspension of microorganisms. Following appropriate incubation conditions, antifungal activity is assessed by measuring the diameter of the growth inhibition zone surrounding the disc (Bosio et al., 2000; Sawaya et al., 2011).

The well technique consists of introducing the propolis extract into wells made in the agar after its inoculation with the microorganism to be tested. The inhibition diameter around the wells is measured to determine the mycelium growth of the pathogen in question. The dilution method is more widely used than the diffusion method to determine mycelium growth. Indeed, incorporation of the extract directly into the culture medium facilitates the dispersal of the active molecules and enables clearer visualization of the extract's activity.

\section{Spore germination}

Spore germination can be assessed with the dilution method in an agar or liquid medium as seen. After incubation, the number of spores is counted with the use of a Malassez cell under a light microscope, and the percentage of spore germination inhibition is determined (Ghaly et al., 1998).

All of these techniques require a negative control without propolis extract so that there is no solvent effect on the inhibition of the tested pathogen. In addition, the presence of positive controls, i.e. such chemical fungicides as amphotericin $\mathrm{B}$, ketoconazole or terbinafine, is an asset as they can be used to compare the activity of the extract to that of some reference molecules (Quiroga et al., 2006; Agüero et al., 2014). Researchers do not often take this parameter into account.

The thin-layer chromatography (TLC)-bioautography method is a more recent technique (Ndjolo, 2012). TLC plates are used to visualize the inhibition zones (representative of activity) 
generated by one or a group of molecules separated beforehand with this method (Moreno et al., 1999; Quiroga et al., 2006; Kasote et al., 2015). The chemical families present in the active fractions are then visualized through fluorescence and/or characterized through HPLC/ MS.

\section{Fungicide activity of propolis against plant pathogen strains}

A list not exhaustive but representative of the studies on the antifungal activity of propolis extract against plant pathogens is presented in Tab. 2, which sums up the results, experimental conditions and methods used. In these studies, antifungal activity was assessed through mycelium growth inhibition (Ozcan et al., 2004; Quiroga et al., 2006; Mohammadzadeh et al., 2007; Meneses et al., 2009; Yang et al., 2011; Curifuta et al., 2012; Haile, \& Dekebo, 2013; Temiz et al., 2013; Ali et al., 2014; Mattiuz et al., 2015; Dudoit et al., 2020), inhibition of spore germination (Ghaly et al., 1998; Mattiuz et al., 2015) or MIC determination (Quiroga et al., 2006; Mohammadzadeh et al., 2007; Agüero et al., 2014; Xu et al., 2019; Hosseini et al. 2020).

Such various plant pathogenic fungi as Fusarium sp., Aspergillus sp., Penicillium sp., Colletotrichum sp., Botrytis cinerea and Aternaria sp. used in these studies to investigate the antifungal activity of propolis extracts came from collections or were isolated from a food matrix (Ozcan et al., 2004; Quiroga et al., 2006; Meneses et al., 2009; Curifuta et al., 2012). Mycelium growth inhibition is usually determined through dilution in an agar medium. Ethanol extracts from Turkey, Ethiopia, Chile and Brazil in studies by Curifuta et al. (2012), Haile \& Dekebo (2013), Mattiuz et al. (2015) and Temiz et al. (2013) showed total inhibition of mycelium growth for the different plant pathogens studied at a concentration of between 2.5 and $5 \%(\mathrm{v} / \mathrm{v})$.

Some works have tested the dose-response effect of propolis ethanol extracts on mycelium growth. Ozcan et al. (2004) and Mattiuz et al. (2015) found that inhibition increased partially and, then completely when the concentration of their Brazilian propolis extract rose from 0.5 to
$2.5 \%(\mathrm{v} / \mathrm{v})$, while an increase from 66 to $89 \%$ inhibition was observed with concentrations of 0.25 and $0.75 \%$ for Chinese propolis. The inhibition percentage rose from 15 to $100 \%$ when the concentration of Turkish propolis rose from 1 to 10\%. Another study by Ozcan et al. (2004) tested the effectiveness of methanol extracts of propolis from five different regions of Turkey at concentrations of $2 \%$ and $5 \%$. Only two propolis extracts displayed total inhibition from a concentration of $5 \%$. The results for these two methanol extracts were similar to those obtained previously with ethanol extracts. However, the methanol extracts of the other three regions showed a substantial inhibiting effect of $52 \%$ at a concentration of $2 \%$.

Four sub-fractions were made up from the same ethanol extract of Chinese propolis with different solvents (ethanol, water, petroleum ether, n-butanol, ethyl acetate) and compared. At an identical concentration (200 $\mathrm{mg} \mathrm{mL}^{-1}$ ), only the ethyl acetate sub-fraction completely inhibited the growth of Penicillium italicum. The inhibition percentages obtained, in decreasing order, were 100, 93, 35, 25 and 6\% for the ethyl acetate, ethanol, petroleum ether, n-butanol and water fractions, respectively (Yang et al., 2011). Interestingly, the initial ethanol extract concentrated at $1200 \mathrm{mg} \mathrm{mL}^{-1}$ did not lead to complete inhibition, but unlike its ethyl acetate sub-fraction though it was six times less concentrated. Meneses et al. (2009) tested the inhibiting power of different fractions of Colombian propolis on: Colletotrichum gloeosporioides strains isolated from mango and papaya and Botryodiplodia theobroma strain isolated from avocado. The four fractions tested were the $n$-hexane/methanol fraction (EPEM), dichloromethane $\left(\mathrm{CH}_{2} \mathrm{Cl}_{2}\right)$, ethyl acetate (EtOAc) and methanol (MeOH). The $\left(\mathrm{CH}_{2} \mathrm{Cl}_{2}\right)$ fraction gave the best results with 47 and $38 \%$ of inhibition for the two strains of $C$. gloeosporioides, while the EPEM fraction led to a better inhibition of the B.theobromae strain. Unfortunately, the authors did not specify what concentrations were used to obtain those results.

Curifuta et al. (2012) and Temiz et al. (2013) chemical fungicides as positive controls (sodium 
benzoate and benzimidazole) in their myceliumgrowth inhibition studies and concluded that the chemical fungicides had a weaker inhibiting activity than the tested propolis extracts. Liquid medium dilution is most frequently used to determine the MIC value and the germination inhibition percentage. Some ethanol extracts of Brazilian propolis were tested against the germination of a Colletotrichum gloeosporioides, the main pathogen of mango anthracnose. The inhibition of $C$. gloeosporioides spore germination is dose-dependent, inhibition of this strain being total beyond a concentration of $2 \%(\mathrm{v} / \mathrm{v})$ propolis extract (Mattiuz et al., 2015). However, worth noting is the exponential effect of the propolis concentration on that inhibition, since the fact of increasing the concentration from 1 to $1.5 \%$ increased inhibition from 47 to $96 \%$. Ghaly et al. (1998) found that their ethanol extract of Egyptian propolis only reduced the spore germination of the 2 Aspergillus isolates by 56 to $76 \%$ for concentrations of between 3 and $4 \mathrm{~g} \mathrm{~L}^{-1}$. In that study, the authors expressed their result as the concentration of initial raw propolis prior to extraction, which in reality amounts to the extraction ratio.

Quiroga et al. (2006) and Agüero et al. (2014) determined similar MIC value (250 vs 232 $\mu \mathrm{g} \mathrm{mL}^{-1}$ ) for their propolis extract originating from different regions of Argentina, extracted through different processes. With a MIC > 250 $\mu \mathrm{mL}^{-1}$, both judged that the Aspergillus strain was not susceptible to the propolis extract used, while Mohammadzadeh et al. (2007) using an ethanol extract of Iranian poplar propolis determined a MIC value of $500 \mu \mathrm{gL} \mathrm{m}^{-1}$ against the same Aspergillus strain. Although their MIC was twice as high as the previous value, Agüero et al. (2014) and Quiroga et al. (2016) concluded that this fungal strain was susceptible to their propolis extract.

Quiroga et al. (2006) also determined the MIC values of the chemical fungicides ketoconazole and clortrimazole and of the isolated and purified flavonoids, pinocembrin and galangin, which they compared to the MIC of the propolis extract on five fungus strains (a strain of Aspergillus, a strain of Penicillium and 3 strains of
Fusarium). The results for the five tested strains indicated MIC values of between 195 and 350 $\mu \mathrm{gL}^{-1}$, between 1 and $8 \mu \mathrm{gL}^{-1}$ and between 25 and $45 \mu \mathrm{gLL}^{-1}$ for the propolis extracts, the chemical fungicides and the isolated flavonoids, respectively. These results lead to the conclusion that the chemical fungicides better inhibited than the isolated compounds, which performed better than the tested propolis extract. The studies undertaken with the TLC-bioautography method confirmed that the active molecules responsible for at least some of the antifungal activity belonged to the family of phenolic compounds (Quiroga et al., 2006; Yang et al., 2011).

\section{Antifungal activity of propolis in vivo}

Due to the recent use of biologically active natural products to treat fruits and vegetables there has been a real research challenge to replace propolis synthetic fungicides for controlling pre and postharvest decay. Propolis has been found to inhibit antifungal postharvest pathogens in vitro. The efficacy of propolis extract on mycelial growth (Ozcan et al., 2004; Yang et al., 2011; Mattiuz et al., 2015) and spore germination (Ghaly et al., 1998; Mattiuz et al., 2015) on phytopathogen strains such as Colletotrichum gloeosporioides, Aspergillus flavus, Alternaria alternata, Fusarium oxysporum, Penicillium italicum has been widely described in literature. Recent studies have been conducted on the application of ethanolic extract of propolis alone or in combination with edible coating on postharvest biopreservation of fruits (Ali et al., 2014; Вarrera et al., 2015; Mattiuz et al., 2015). Interesting results have been obtained in vivo on the efficacy of propolis as an alternative process for food preservation. However, no request or approval documents have been made to introduce propolis on the market in plants and crops protection. The use of a natural extract or active substance must be approved as a basic substance by European Commission and listed in Regulation (EU) N 540/2011.

Mattiuz et al. (2015) reported that the ethanolic extract of propolis (EEP) did not limit the growth of C. gloeosporioides on mango the first 
fourteen days of storage, but on day 21 the treatment significantly reduced lesion areas on mango compared to control. Matny et al. (2015) also reported the efficacy of Iraqi EEP to control and reduce apple fruit decay. EEP treatment reduced mold area by $66.8 \%$ compared with untreated fruit against $P$. expansum. Giovanelli (2008) showed the potential of South African EEP to inhibit post-harvest diseases and prevent infection caused by Colletotrichum on avocado fruit.

In these two studies, fruits were first inoculated with $15 \mu \mathrm{L}$ of Colletotrichum sp. conidia $(1 \mathrm{x}$ $10^{5}$ conidia $\left.\mathrm{mL}^{-1}\right)$. To understand the preventive action of EEP against Colletotrichum, fruits were immediately sprayed with $5 \mathrm{mg} \mathrm{mL}^{-1}$ (MIC value) and $10 \mathrm{mg} \mathrm{mL}^{-1}$ EEP. Whereas in the study on the efficacy of EEP to inhibit disease symptoms of infected fruit, these fruit were treated twentyfour hours after infection. In both cases, the use of $5 \mathrm{mg} \mathrm{mL}^{-1}$ and $10 \mathrm{mg} \mathrm{mL}^{-1}$ EEP on the postharvest treatment of avocado fruit inoculated with Colletotrichum conidia evidenced a similar potential to inhibit disease symptoms compared with untreated fruit. Similarly, Moraes et al. (2011) has proved the efficiency of 10\% propolis extract concentration for the control of powdery mildew in tomato plants. Lastly, Matny (2015) soaked oranges with concentrations of 1 , 2 and 3\% EEP from Baghdad, Iraq, for the control of Penicillium digitatum pathogen causeing gray mold, and found that 3\% more efficiently inhibited disease severity. All EEP treatment still showed a fungicidal activity compared with pathogen treatment only. The effect of $1 \%, 2 \%$ and $3 \%$ EEP on disease incidence was respectively $66.67 \%$, 33.34\% and $22.23 \%$.

Few studies deal with the efficacy of propolis incorporated into edible films. Ali et al. (2014) reported the use of EEP and edible coating with gum arabic (GA) and EEP to control anthracnose of papaya caused by C. gloeosporioides. After a four-week storage, $1.5 \%$ EEP treatment alone or in combination with 10\% GA concentration provided a disease incidence reduction of $80 \%$ compared with control fruit. Barrera et al. (2015) investigated the application of an edible propolis coating on fruit to minimize postharvest decay.
Compared to water-coating control, a coating of chitosan and EEP treatment on papaya during storage against C. gloeosporioides reduced lesion diameter In vivo results revealed that propolis could be a natural antifungal substitute to the actual chemical fungicide for control postharvest diseases of fruits and vegetables.

\section{DISCUSSION}

The pharmaceutical-biological activities suggested for propolis are numerous and consistent with the increase in the number of studies published in recent years on this natural substance. However, propolis has yet to acquire official legitimacy in the eyes of the medical profession.

All the studies confirmed that their propolis extract more or less displayed an antifungal activity. However, the objective of any scientific work is to provide knowledge that is reproducible by anyone and useable by the entire scientific community in order to make headway on this subject. If there is to be any hope of learning practical lessons that are exploitable in the field, it must be possible to compare the results of all these studies. Yet, if the results presented here are examined more closely, it can be seen that some authors express their concentrations as a percentage of the volume of propolis solution compared to the volume of culture broth, while others express it as weight per volume of solution. However, who can say how and what the active ingredient contents of the propolis solution are when expressed as a \% of the volume, or who can say what this weight of "so-called propolis" corresponds to exactly? Some have described it as being raw propolis prior to extraction, for example, but that could just as well mean the dry matter weight after extraction or the weight of active ingredients. Some authors state that their propolis extract, given its MIC value, is more active than some chemical fungicides, while others clearly show the opposite. How can it be explained that two pure flavonoids typically found in certain extracts of propolis have a MIC up to fifteen times more effective than the ethanol extract 
of propolis?

In brief, the questions come rapidly when attempting to compare all these results. All this because there are many factors of variation in these studies which are not specified and which ultimately make the results uncomparable and unusable. EFSA had already disapproved of this in 2010 after "health" claim applications for propolis reporting that, "From the references cited, the panel notes that the type and content of flavonoid in propolis may vary depending on the specific raw material as well as the extraction and preparation methods."

Insofar as propolis is a natural substance it displays a degree of variability. The name propolis has nothing specific, just like the word "fruit"; there is nothing in this word to indicate whether an apple, an apricot or a cherry is involved, yet the shape, texture and active ingredients of each of these elements which are called "fruits" will be very different. As seen in the first section, the botanical sources that give rise to propolis are very numerous. It is therefore essential to identify the botanical origin of propolis and no longer its geographical origin, thereby already limiting the degree of variation. Yet this is not enough if exploitable results are to be produced, because there are many sources of variation in propolis extracts. First of all, it was seen that the harvesting method affects the proportion of beeswax and thereby the amount of plant resin which contains the active ingredients responsible for biological activity, but these activities are never assessed with raw propolis but with extracts. The extraction stages and preparation of the extract to be tested on the biological system involve a multitude of sources of variation which, here again, will make the result unusable unless all these processes are fully and clearly specified. The most common sources of variation in the literature are the types of extraction solvent used (ethanol, methanol, dichloromethane, ethyl acetate, petroleum ether, butanol or water) (Meneses et al., 2009; Yang et al., 2011), the extraction ratio (what quantity of raw propolis for what volume of solvent, ranging from $1 / 3$ to $1 / 50$ ), the time (from 2 hours to 2 weeks) and the extraction temperature (from room temperature to $60^{\circ} \mathrm{C}$ ). Then comes the mixture filtration stage, leading to a liquid extract. This extract may be used on the biological system either directly or evaporated until dry and resolubilized in a new volume and maybe even a new solvent, or rediluted. In practice, all these different stages are rarely perfectly described, but let us imagine two perfectly independent studies both using a propolis identified as being from poplar, for example, and each preparing its extract by the same process and testing the antifungal activity of their extract on the same plant pathogen strain under the same experimental conditions. In this example, the only possible conclusion would be that the extract of one has a better or lesser antifungal activity than the other. In order to compare this result to those of other studies, it would be necessary for all the studies to be carried out under exactly the same experimental conditions, from identification of the botanical origin of the propolis up to preparation of the extract. Such a result could not be reproduced, since with the existing degree of natural variability, the exactly same sample of raw propolis will never be found twice. Lastly, this result would be exploitable if a propolis of unknown botanical origin were used, the only possible conclusion would be to say that it would seem to be more or less active than the other. However, under no circumstances would the results contribute to a better general knowledge of propolis.

Biological activities are due to the presence of active compounds which are derived from the botanical source of the resin. Determining the active ingredient content of the extract actually deposited in the biological system would completely do away with the need to precisely describe all the preparation stages and make it possible to compare the results of these studies on a common basis: the active ingredient content. The question of standardizing propolis extracts, already raised by Bankova (2005a) might be the best solution for enhancing knowledge, but the question is how and on what basis can such standardization be carried out. The active ingredients of propolis belong 
to the large family of the polyphenols, with all the sub-classes. Popova et al. (2004) validated a standardization method for poplar propolis based on three criteria determined by spectrophotometry: total flavone and flavonol content, total flavanone and dihydroflavonol content and the total polyphenol content. A method has also been validated on poplar propolis based on the analysis of flavonoids only. Some validated methods exist but are not used because first of all the Folin-Ciocalteu reagent used to analyse total polyphenols by spectrometry is known to react not only to the latter, suggesting possible overestimation. A comparison of the method by Popova et al. (2004) and Cvek et al. (2007) also shows that using different standards for calibration curves is a further source of variation. Moreover, Popova et al. (2004) had established a specific standard for poplar propolis based on the relative proportions of the different subclasses of polyphenols present in that specific propolis.

Another idea would be to standardize according to one compound. For example, such biologically active compounds as the CAPE molecule (caffeic acid phenethyl ester) existing in poplar propolis do not exist in propolis samples from a tropical climate. Conversely, artepillin C, a majority compound of green propolis from Brazil obtained from Baccharis dracunculifolia, does not exist in any temperate-climate propolis from a. Under such conditions, it is difficult to choose a molecule being a marker of all the propolis samples.

The question of standardizing propolis therefore goes unanswered as there is not any single method representative of all the different types of propolis. However, pending a consensual method being found it is necessary, to make use of the current means of analysing the active ingredients of propolis and enable standardization. A recent review lists the reference validated methods to be adapted to analyse the active ingredients of propolis as well as the methods to estimate the antimicrobial and antioxidant potential of the extracts of propolis (Bankova et al., 2016).

\section{CONCLUSION}

Many studies have been devoted to propolis and its attributed biological activities. However, its properties have yet to be legitimately acknowledged, due to a lack of rigour in characterizing the botanical origin of this substance and the virtually systematic absence of the active ingredient content of the tested extracts. In the future, all researchers and authors will have pay attention to the existence of these data if concrete, reproducible and exploitable lessons are to be learnt. It is at the cost of such thoroughness that propolis may see its official status correspond to the numerous biological promises attributed to it.

\section{Conflict of interest}

All authors stated that no conflict of interest exists.

\section{REFERENCES}

Agüero, M. B., Svetaz, L., Baroni, V., Lima, B., Luna, L., Zacchino, S., ... Tapia, A. (2014). Urban propolis from San Juan province (Argentina): Ethnopharmacological uses and antifungal activity against Candida and dermatophytes. Industrial Crops and Products, 57, 166-173. DOl: 10.1016/j.indcrop.2014.03.009

Ali, A., Cheong, C. K., Zahid, N. (2014). Composite Effect of Propolis and Gum Arabic to Control Postharvest Anthracnose and Maintain Quality of Papaya during Storage. International Journal of Agriculture \& Biology, 16, 1117-1122.

Ali, A., Wei, Y. Z., Mustafa, M. A. (2014). Exploiting Propolis as an Antimicrobial Edible Coating to Control Post-harvest Anthracnose of Bell Pepper. Packaging Technology and Science, DOl: 10.1002/pts.2088

Almas, K., Dahlan, A., Mahmoud, A. (2001). Propolis as a Natural Remedy - an Update. Saudi Dental Journal, $73(1), 45-49$.

Bankova, V. (2005a). Chemical diversity of propolis and the problem of standardization. Journal of Ethnopharmacology, 1001-2), 114-117. DOl: 


\section{- DUDOITETH.}

\subsection{6/j.jep.2005.05.004}

Bankova, V. (2005b). Recent trends and important developments in propolis research. Evidence Based and Complementary Alternative Medicine, 2(1), 2932. DOl: 10.1093/ecam/neh059

Bankova, V., Bertelli, D., Borba, R., Conti, B. J., da Silva Cunha, I. B., Danert, C., .. Zampini, C. (2016). Standard methods for Apis mellifera propolis research. Journal of Apicultural Research, 58(2), 1-49. DOl: 10.1080/00218839.2016.1222661

Bankova, V., Casro, S. L., Marcucci, M. C. (2000), Propolis, recent advances in chemistry and plant origin. Apidologie, 37(1), 3-15. DOl: 10.1051/ apido:2000102

Bankova, V., Popova, M., Bogdanov, S., Sabatini, A. G (2002). Chemical Composition of European Propolis, Expected and Unexpected Results. Zeitschrift für Naturforschung C, 57, 530-533. DOl: 10.1515/znc2002-5-622

Bankova, V., Popova, M., Trusheva, B. (2014). Propolis volatile compounds: chemical diversity and biological activity: a review. Chemistry Central Journal, 8, 1-8. DOl: 10.1186/1752-153X-8-28

Banskota, A. H., Tezuka, Y., Kadota, S. (2001). Recent progress in pharmacological research of propolis. Phytotherapy Research, 15(7), 561-571. DOl: 10.1002/ptr.1029

Barrera, E., Gil, J., Restrepo, A., Mosquera, K., Durango, D. (2015). A coating of chitosan and propolis extract for the postharvest treatment of papaya (Carica papaya L. cv. Hawaiiana). Revista Facultad Nacional de Agronomía, 68(2), 7667-7678. DOl: 10.15446/ rfnam

Basim, E., Basim, H. Özcan, M. (2006). Antibacterial activities of Turkish pollen and propolis extracts against plant bacterial pathogens. Journal of Food Engineering, 774), 992-996. D0l: 10.1016/j. jfoodeng.2005.08.027

Bosio, K., Avanzini, C., D’Avolio, A., Ozino, O., Savoia,
D. (2000). In vitro activity of propolis against Streptococcus pyogenes. Letters on Applied Microbiology, 37, 174-177. DOl: 10.1046/j.13652672.2000.00785.x

Burdock, G. A. (1997). Review of the Biological Properties and Toxicity of Bee Propolis (Propolis). Food and Chemical Toxicity, 36, 347-363. DOl: 10.1016/S0278-6915(97)00145-2

Castaldo, S., \& Capasso, F. (2002). Propolis, an old remedy used in modern medicine. Fitoterapia, 73(1), S1-S6. DOI: 10.1016/S0367-326X(02)00185-5

Castro, M. L., Vilela, W. R., Zauli, R. C., Ikegaki, M., Rehder, V. L., Foglio, M. A., ... Rosalen, P. L. (2009). Bioassay guided purification of the antimicrobial fraction of a Brazilian propolis from Bahia state. BMC Complementary and Alternative Medicine, 9, 25. D0l:10.1186/1472-6882-9-25

Catchpole, O. J., Grey, J., Mitchell, K., Lan, J. (2004). Supercritical antisolvent fractionation of propolis tincture. The Journal of Supercritical Fluids, 29(1), 97-106.

Curifuta, M., Vidal, J., Salazar, L. A., Sánchez-Venegas, J. Alvear, M., Contreras, A. (2012). The in vitro antifungal evaluation of a commercial extract of Chilean propolis against six fungi of agricultural importance. Ciencia e Investigación Agraria, 39(2), 347-359.

Cvek, J., Medic-Saric, M., Jasprica, I., Zubcic, S., Vitali, D., Mornar, A., ... Tomic, S. (2007). Optimisation of an extraction procedure and chemical characterisation of Croatian propolis tinctures. Phytochemical Analysis, 18(5), 451-459. D0l: 10.1002/pca.1001

de Funari, C. S., de Oliveira Ferro, V., Mathor, M. B. (2007). Analysis of propolis from Baccharis dracunculifolia DC. (Compositae) and its effects on mouse fibroblasts. Journal of Ethnopharmacology, 177(2), 206-212. DOl: 10.1016/j.jep.2006.11.032

Dobrowolski, J. W., Vohorab, S. B., Sharmab, K. Shahb, S. A., Naqvib, S. A. H., Dandiyab, P. C. (1991). Antibacterial, antifungal, antiamoebic, 


\section{J. APRC. SCLI. VOL. 65 NO. 1 2021}

antiinflammatory and antipyretic studies on propolis bee products. Journal of Ethnopharmacology, 32, 77-82. DOl: 10.1016/0378-8741(91)90135-Z

Dota, K. F., Consolaro, M. E., Svidzinski, T. I., Bruschi, M. L. (2011). Antifungal Activity of Brazilian Propolis Microparticles against Yeasts Isolated from Vulvovaginal Candidiasis. Evidence Based Complementary and Alternative Medicine, 2017. DOl: 10.1093/ecam/neq029

Dudoit, A., Mertz, C., Chillet, M., Cardinault, N., Brat, P. (2020). Antifungal activity of Brazilian red propolis extract and isolation of bioactive fractions by thin-layer chromatography-bioautography. Food Chemistry, 327, 1-8. DOl: 10.1016/j. foodchem.2020.127060

Falcão, S.lı, Vilas-Boas, M., Estevinho, L.M., Barros, C., Domingues, M.R., Cardoso, S.M. (2010). Phenolic characterization of Northeast Portuguese propolis: Usual and unusual compounds. Analytical and Bioanalytical Chemistry, 396, 887-897.

Farooqui, T., \& Farooqui, A. A. (2012). Beneficial effects of propolis on human health and neurological diseases. Frontiers in Bioscience, 4,779-793.

Ferhoum, F. (2010). Analyses physico chimiques de la propolis locale selon les étages bioclimatiques et les deux races d'abeille locales (Apis mellifera intermissa et Apis mellifera sahariensis). Mémoire de magister en Technologie alimentaire, Université de M'hamed Bougara Boumerdès

Fokt, H., Pereira, A., Ferreira, A. M., Cunha, A., Aguiar, C. (2010). How do bees prevent hive infections, The antimicrobial properties of propolis. Current Research, Technology and Education Topics in Applied Microbiology and Microbial Biotechnology, T, 481-493.

Gardana, C., Scaglianti, M., Pietta, P., Simonetti, P. (2007). Analysis of the polyphenolic fraction of propolis from different sources by liquid chromatography-tandem mass spectrometry. Journal of Pharmaceutical and Biomedical Analysis, 45(3), 390-399. DOl: 10.1016/j.jpba.2007.06.022
Garedew, A., Schmolz, E., Lamprecht, I. (2004). Microbiological and calorimetric investigations on the antimicrobial actions of different propolis extracts: an in vitro approach. Thermochimica Acta, 422(1-2), 115-124. DOl: 10.1016/j.tca.2004.05.037

Ghaly, M. F., Ezzat, S. M., Sarhan, M. M. (1998). Use of propolis and ultragriseofulvin to inhibit aflatoxigenic fungi. Folia Microbiologica, 43(2), 156-160. DOl: 10.1007/BF02816502

Ghedira, K., Goetz, P., Jeune, R. (2009). Propolis. Phytothérapie, 72), 100-105. DOl: 10.1007/s10298009-0377-8

Giovanelli, L. C. (2008). Evaluation of an Ethanolic Extract of Propolis as a Potential Pre-and Postharvest Fungicide of 'fuerte' Avocado (Persea Americana Mill.) Fruits and Orchids (Doctoral dissertation, University of the Witwatersrand)

Guginski-Piva, C. A., Santos, I. d., Júnior, A. W., Heck, D. W., Flores, M. F., Pazolini, K. (2015). Propolis for the control of powdery mildew and the induction of phytoalexins in cucumber. IDESIA (Chile), 33(1), 3947. DOI: 10.4067/S0718-34292015000100005

Haile, K., \& Dekebo, A. (2013). Chemical composition and antimicrobial activity of Haramaya propolis (bee glue), Ethiopia. International Journal of Pharmaceutical Sciences and Research, 4(2), 734740.

Hegazi, A. G., Hadyb, F. K. A. E., Allah, F. A. M. A. (2000). Chemical Composition and Antimicrobial Activity of European Propolis. Zeitung Naturforschung, 55(1-2), 70-75. DOl: 10.1515/znc-2000-1-214

Herrera, C. L., Alvear, M., Montenegro, G., Barrientos, L., Salazar, L. A. (2010). The antifungal effect of six commercial extracts of Chilean propolis on Candida spp. Ciencia e Investigación Agraria, 371), 75-84. DOl: 10.4067/S0718-16202010000100007

Hosseini, H. M., Pour, S. H., Amani, J., Jabbarzadeh, S., Hosseinabadi, M., Mirhosseini, S. A. (2020). The effect of Propolis on inhibition of Aspergillus parasiticus growth, aflatoxin production and expression of 
aflatoxin biosynthesis pathway genes. Journal of Environmental Health Science and Engineering, 1-6.

Kasote, D., Ahmad, A., Chen, W., Combrinck, S., Viljoen, A. (2015). HPTLC-MS as an efficient hyphenated technique for the rapid identification of antimicrobial compounds from propolis. Phytochemistry Letters, 17, 326-331. D0l: 10.1016/j.phytol.2014.08.017

Kumazawa, S., Hayashi, K, Kajiya, K., Ishii, T., Hamasaka, T., Nakayama, T. (2002). Studies of the constituents of Uruguayan propolis. Journal of Agricultural and Food Chemistry, 50, 4777-4782. DOl: 10.1021/ jf020279y

Kumazawa, S., Nakamura, J., Murase, M., Miyagawa, M., Ahn, M.-R., Fukumoto, S. (2008). Plant origin of Okinawan propolis: Honeybee behavior observation and phytochemical analysis. Naturwissenschaften, 95, 781-786.

Marcucci, M. (1995). Propolis chemical composition, biological properties and therapeutic activity. Apidologie, 26, 83-99.

Markham, K. R., Mitchell, K. A., Wilkins, A. L., Daldy, J. A., Lu, Y. (1996). HPLC and GC-MS identification of the major organic constituents in New Zeland propolis. Phytochemistry, 42(1), 205-211

Matny, O. N. (2015). Efficacy Evaluation of Iraqi Propolis Against Gray Mold of Stored Orange Caused by Penicillium digitatum. Plant Pathology Journal, 14(3), 153-157. D0l:10.3923/ppj.2015.153.157

Matny, O. N., AL-Warshan, S. H. S., Ali, A. M. (2015). Antifungal Evaluation of Iraqi Propolis against Penicillium expansum and Mycotoxin Production in Apple. International Journal of Current Microbiology and Applied Science, 4(11), 399-405.

Mattiuz, B.-H., Ducamp-Collin, M.-N., Mattiuz, C. F. M., Vigneault, C., Marques, K. M., Sagoua, W., Montet, D. (2015). Effect of propolis on postharvest control of anthracnose and quality parameters of 'Kent' mango. Scientia Horticulturae, 184, 160-168. DOl: 10.1016/j.scienta.2014.12.035
Meneses, E. A., Durango, D. L., García, C. M. (2009). Antifungal activity against postharvest fungi by extracts from Colombian propolis. Quimica Nova, 32(8), 2011-2017.

Mohammadzadeh, S., Shariatpanahi, M., Hamedi, M., Ahmadkhaniha, R., Samadi, N., Ostad, S. N. (2007). Chemical composition, oral toxicity and antimicrobial activity of Iranian propolis. Food Chemistry, 103(4), 1097-1103.

Mora, M. Q., Orozco, A. L., Zárate, C. S., Tovar, C. G., Miranda, L. C., Carrillo, J. P., Sánchez, T. C. (2011). Structural and genetic alterations of fungal cells caused by mexican propolis. Science Against Microbial Pathogens: Communicating Current Research and Technological Advances, 1068-1073.

Moraes, W. B., Jesus Junior, W. C. d., Belan, L. L., Peixoto, L. d. A., Pereira, A. J. (2011). AplicaÇÃo Foliar De Fungicidas E Produtos Alternativos Reduz a Severidade Do Oĺdio Do Tomateiro. Nucleus, 8(2), 57-68. DOl: 10.3738/1982.2278.554

Moreno, M. I. N., Isla, M. I., Cudmani, N. G., Vattuone, M. A., Sampietre, A. R. (1999). Screening of antibacterial activity of Amaicha del Valle (Tucuman, Argentina) propolis. Journal of Ethnopharmacology, 68(1-3), 97102.

Ndjolo, P. O. (2012). Etude phytochimique et activité antimicrobienne directe et indirecte de Cordia gilletii de Wild (Boraginaceae). https://citeseerx.ist.psu.edu/ viewdoc/download?doi=10.1.1.462.8809\&гер=гер1 \&type=pdf

Nedji, N., \& Loucif-Ayad, W. (2014). Antimicrobial activity of Algerian propolis in foodborne pathogens and its quantitative chemical composition. Asian Pacific Journal of Tropical Disease, 4(6), 433-437. DOl: 10.1016/s2222-1808(14)60601-0

Ota, C., Unterkircher, C., Fantinato, V., Shimizu, M. T. (2001). Antifungal activity of propolis on different species of candida. Mycoses, 44, 375-378. DOl: 10.1046/j.1439-0507.2001.00671.x

Ozcan, M., Unver, A., Ceylan, D. A., Yetisir, R. 


\section{Ј. APPC. SCL. VOL. 65 IIV. 12021}

(2004). Inhibitory effect of pollen and propolis extracts. Nahrung, 48(3), 188-194. DOl: 10.1002/ food.200300296

Park, Y. K., Paredes-Guzman, J. F., Aguiar, C. L., Alencar, S. M., Fujiwara, F. Y. (2004). Chemical Constituents in Baccharis dracunculifolia as the Main Botanical Origin of Southeastern Brazilian Propolis. Journal of Agricultural and Food Chemistry, 52, 1100-1103. DOl: 10.1021/jf021060m

Pietta, P. G., Gardana, C., Pietta, A. M. (2002). Analytical methods for quality control of propolis. Fitoterapia, 73, S7-S20. DOl: 10.1016/S0367-326X(02)00186-7

Popova, M., Bankova, V., Butovska, D., Petkov, V., Nikolova-Damyanova, B., Sabatini, A. G..... Bogdanov, S. (2004). Validated methods for the quantification of biologically active constituents of poplar-type propolis. Phytochemical Analysis, 15(4), 235-240. DOl: 10.1002/pca.777

Quiroga, E. N., Sampietro, D. A., Soberon, J. R., Sgariglia, M. A., Vattuone, M. A. (2006). Propolis from the northwest of Argentina as a source of antifungal principles. Journal of Applied Microbiology, 107(1), 103-110. DOl: 10.1111/j.1365-2672.2006.02904.x

Ramos, A. F. N. (2007). Propolis: a review of its antiinflammatory and healing actions. The journal of Venomous Animals and Toxins Including Tropical Diseases, 13(4), 697-710. DOl: 10.1590/S167891992007000400002

Sahinler, N., \& Kaftanoglu, O. (2005). Natural product propolis: Chemical composition. Natural Products Chemistry And Research, 19, 183-188.

Salatino, A., Teixeira, E. W., Negri, G., Message, D. (2005). Origin and Chemical Variation of Brazilian Propolis. Evidence-Based Complementary and Alternative Medicine, 2(1), 33-38. DOl: 10.1093/ ecam/neh060

Salomao, K., Pereira, P.R., Campos, L.C., Borba, C.M., Cabello, P.H., Marcucci, M.C., de Castro, S.L. (2008). Brazilian propolis: correlation between chemical composition and antimicrobial activity. Evidence-
Based Complementary and Alternative Medicine, 5, 317-324. DOl: 10.1093/ecam/nem058

Sawaya, A. C., Barbosa da Silva Cunha, I., Marcucci, M. C. (2011). Analytical methods applied to diverse types of Brazilian propolis. Chemistry Central Journal, 5(1), 1-10. DOl: 10.1186/1752-153X-5-27

Sawaya, A. C. H. F., Tomazela, D. M.; Cunha, I. B. S., Vassya, S., Bankova, V. S., Maria, C., ... Eberlin, M. N. (2004). Electrospray ionization mass spectrometry fingerprinting of propolis. Analyst, 129, 739-744. DOl: $10.1039 / B 403873 \mathrm{H}$

Sforcin, J. M. (2007). Propolis and the immune system: a review. Journal of Ethnopharmacology, 173(1), 1-14. DOl: 10.1016/j.jep.2007.05.012

Silva-Carvalho, R., Baltazar, F., Almeida-Aguiar, C. (2015). Propolis: A Complex Natural Product with a Plethora of Biological Activities That Can Be Explored for Drug Development. Evidence Based Complementary Alternative Medicine, 2015. D0l: 10.1155/2015/206439

Silva, B. B., Rosalen, P. L., Cury, J. A., Ikegaki, M., Souza, V. C., Esteves, A., Alencar, S. M. (2008). Chemical composition and botanical origin of red propolis, a new type of brazilian propolis. Evidence Based Complementary Alternative Medicine, 5(3), 313-316. DOl: 10.1093/ecam/nem059

Stan, L., Mărghitaş, L. A., Dezmirean, D. (2011). Quality criteria for propolis standardization. Scientific Papers Animal Science and Biotechnologies, 44(2), 137-140

Temiz, A., Mumcu, A. Ş., Tüylü, A. Ö., \& Sorkun, K. (2013). Antifungal activity of propolis samples collected from different geographical regions of Turkey against two food-related molds, Aspergillus versicolor and Penicillium aurantiogriseum. GIDA, 38(3), 135-142. DOl: 10.5505/gida.2013.10820

Tolba, M. F., Azab, S. S., Khalifa, A. E., Abdel-Rahman, S. Z., Abdel-Naim, A. B. (2013). Caffeic acid phenethyl ester, a promising component of propolis with a plethora of biological activities: a review on its antiinflammatory, neuroprotective, hepatoprotective, 


\section{- OUDOITETH.}

and cardioprotective effects. International Union of Biochemistry and Molecular Biology Life, 65(8), 699709. DOl: 10.1002/iub.1189

Toreti, V. C., Sato, H. H., Pastore, G. M., Park, Y. K. (2013). Recent progress of propolis for its biological and chemical compositions and its botanical origin. Evidence Based Complementary Alternative Medicine, 2013,697390. DOl: 10.1155/2013/697390

Tosi, E. A., Ciappini, M. C., Cazzolli, A. F., Tapiz, L. M. (2006). Physico chemical characteristics of propolis collected in Santa Fe. Apiacta, 47, 110-120.

Tran, V.H., Duke, R.K., Abu-Mellal, A., Duke, C.C. (2012), Propolis with high flavonoid content collected by honey bees from Acacia paradoxa. Phytochemistry, 81, 126-132. DOl: 10.1016/j.phytochem.2012.06.002

Valencia, D., Alday, E., Robles-Zepeda, R., GaribayEscobar, A., Galvez-Ruiz, J. C., Salas-Reyes, M., ... . Velazquez, C. (2012). Seasonal effect on chemical composition and biological activities of Sonoran propolis. Food Chemistry, 137(2), 645-651. D0l: 10.1016/j.foodchem.2011.08.086

Vardar-Ünlü, G., Silici, S., Ünlü, M. (2007). Composition and in vitro antimicrobial activity of Populus buds and poplar-type propolis. World Journal of Microbiology and Biotechnology, 24(7), 1011-1017. DOl: 10.1007/s11274-007-9566-5

Velikova, M., Bankova, V., Marcuccib, M. C., Tsvetkova, I., Kujumgiev, A. (2000). Chemical Composition and Biological Activity of Propolis from brazilian meliponinae. Zeitschrift für Naturforschung, 55(1), 785-789. DOl: 10.1515/znc-2000-9-1018

Walker, P., \& Crane, E. (1987). Constituents of propolis. Apidologie, 18(4), 327-334

Watanabe, M. A., Amarante, M. K., Conti, B. J., \& Sforcin, J. M. (2011). Cytotoxic constituents of propolis inducing anticancer effects: a review. Journal of Pharmacy and Pharmacology, 63(11), 1378-1386. DOl: 10.1111/j.2042-7158.2011.01331.x
Xu, Y., Luo, L., Chen, B., Fu, Y. (2009). Recent development of chemical components in propolis. Frontiers of Biology in China, 4(4), 385-391. DOl: 10.1007/s11515-009-0053-2

$X u, X ., P u, R$., Li, Y., Wu, Z., Li, C., Miao, X., Yang, W. (2019). Chemical Compositions of Propolis from China and the United States and their Antimicrobial Activities Against Penicillium notatum. Molecules, 24(19), 3576. DOl: 10.3390/molecules24193576

Yaghoubi, S. M. J., Ghorbani, G. R., Soleimanian ZAD, S., Satari, R. (2007). Antimicrobial activity of Iranian propolis and its chemical composition. Daru Journal of Pharmaceutical Sciences, 15(1), 45-48.

Yang, S. Z., Peng, L. T., Su, X. J., Chen, F., Cheng, Y. J., Fan, G., Pan, S. Y. (2011). Bioassay-guided isolation and identification of antifungal components from propolis against Penicillium italicum. Food Chemistry, 1271), 210-215. http://dx.doi.org/10.1016/j. foodchem.2010.12.011 